\title{
Organizing Democracy through General Elections in Indonesia: The Challenge of Law Enforcement and State Stability
}

Ridwan Arifin ${ }^{1}$, Saktiani Nurul Hidayat ${ }^{2}$

ridwan.arifin@mail.unnes.ac.id1, nurulsasa121@gmail.com²

${ }^{12}$ Faculty of Law, Universitas Negeri Semarang (UNNES), Jl. Kampus Timur, Sekaran, Gunung Pati, Semarang City, Central Java 50229

\begin{abstract}
One of the developments in Indonesia's political democracy is marked by the existence of legal framework that state sovereignty belongs to the people and is carried out in accordance with the 1945 Constitution. On the basis of the formulation of leadership succession in the executive and legislative branches it is mandated by Article $22 \mathrm{E}$ paragraph (2). However, in practice the constitutional arrangement in Law Number 42 of 2008 concerning the General Election of the President and Vice President shows that it is inconsistent with statements in the constitution. As stipulated in Article 3 paragraph (5) states that the election of the President and Vice President is held after the election of the DPR, DPD and DPRD. At the end of the Constitutional Court through Decree No. 14/PUU-XI/2013 states that the selection of models is unconstitutional. Based on this assessment the constitutionality of the norm selection method is based on the simultaneous interpretation of the constitution both from the initial intentions and historical interpretations. The simultaneous constitutional electoral plan was called born as an effort to shift the direction of the transition to democracy in a strengthening system so that democratic consolidation of direct democratic practices tends to be transactional, corrupt, manipulative, high cost and to preserve power can be minimized in the practice of constitutional democratic dimensions to understand and sovereignty.
\end{abstract}

Keywords: democracy, general elections, law enforcement, state stability

\begin{abstract}
Abstrak
Salah satu perkembangan demokrasi politik di Indonesia ditandai dengan adanya kerangka hukum yang menyebutkan bahwa kedaulatan negara adalah milik rakyat dan dilaksanakan sesuai dengan UUD 1945. Atas dasar rumusan suksesi kepemimpinan di lembaga eksekutif dan legislatif itu diamanatkan oleh Pasal $22 \mathrm{E}$ ayat (2). Namun, dalam praktiknya pengaturan konstitusional dalam Undang-Undang Nomor 42 Tahun 2008 tentang Pemilihan Umum Presiden dan Wakil Presiden menunjukkan bahwa hal itu tidak sesuai dengan pernyataan dalam konstitusi. Sebagaimana diatur dalam Pasal 3 ayat (5) yang menyatakan bahwa pemilihan Presiden dan Wakil Presiden diadakan setelah pemilihan DPR, DPD dan DPRD. Pada akhirnya Mahkamah Konstitusi melalui Keputusan No. 14 / PUU-XI / 2013 menyatakan bahwa model pemilihan tersebut adalah inkonstitusional. Berdasarkan hal ini, konstitusionalisasi norma dalam metode pemilihan didasarkan pada interpretasi simultan konstitusi baik dari niat awal maupun interpretasi historis. Rencana pelaksanaan pemilu konstitusional simultan disebut lahir sebagai upaya untuk menggeser arah transisi ke demokrasi dalam sistem penguatan sehingga konsolidasi demokrasi melalui praktik demokrasi langsung cenderung transaksional, korup, manipulatif, biaya tinggi dan upaya mempertahankan kekuasaan dapat diminimalisir dalam dimensi praktik demokrasi konstitusional.
\end{abstract}

Kata kunci: demokrasi, pemiliban umum, penegakan hukum, stabilitas negara 


\section{Introduction}

Indonesia embraced Pancasila as a democratic system. Pancasila is the state ideology. Indonesian democracy has a basis of distribution of power consist of legislative, executive, and judicial branches to be called as political principles. Based on three powers, Indonesian political system is running to be not mutually exclusive and share power equally based on its political functions (Romadhan; Khanifah; Sihidi; \& Kamil., 2019). Democracy means all decisions and sovereignty are in the hands of the people, and elections are the process of electing officials (Mulyadi \& Utami, 2017). The citizen who comply with the criteria also has a right to be elected, and deserves to be the leader of the State. Whereas, the author has different perspective about the implementation of general election in Indonesia.

According to Austin Ranney there are basic criteria for democratic elections, namely: (a) General suffrage. Elections are only called democratic if all adult citizens enjoy passive and active suffrage. If restrictions are made, this must be determined democratically, namely through law. In modern life, the limitation can only be understood if it is based on the inability of a person to accept his state social responsibility. (b) Equivalent weight of votes. There must be a guarantee that the votes of each voter are given the same weight, meaning that there should not be group of citizens, whatever their position, life history, and services, which get more representatives from other citizens. For example, it is determined that each parliamentary seat is worth 420,000 votes, so there must be a guarantee that no group of citizens whose number is less than the quota gets one or even more seats in parliament. (c) Equation of campaign rights. The work program and superior candidates will have no meaning if they are not recognized by the mass of voters. Therefore, the campaign has become very important in the electoral process. Through this process the mass of voters was introduced to the candidates and the work program of the election contestants.

The first time the presidential election and legislative elections were held simultaneously for 2019 for now which is being discussed in Indonesian society is the election campaign for the former corruption and legislative elections and inmates. Joko Widodo's first nominee candidates paired with KH. Ma'ruf Amin and candidate number two are Prabowo Subianto and Sandiaga Uno. On September 23, 2018 the KPU set a number of rules for election participants for the campaign which took place from September 23, 2018 to April 13, 2019. The rules for the 2019 election campaign include; 1) Do not advertise in mass media before the campaign period, 2) Advertisements during the campaign period can only be for 21 days which end with the start of the calm period, 3) It is prohibited to place political party flags and serial numbers of election participants other than in places that have been arranged, 4) It is forbidden to post images of state officials including the president and vice president and former president and vice president (except the general chairman of the party) on the props, 5) The mass media must provide equal opportunity to election participants in the election and display of campaign advertisements, 6) Prohibited from using government facilities, places of worship, and places of education, 7) It is prohibited to carry or use images and attributes other than images or attributes of election participants, 8) Prohibited from holding closed meetings without reporting to the KPU and Bawaslu 
When the KPU reads the rules of the election, the candidates and their partners shake hands to carry out a positive peace campaign (Yustikarini, Alika, \& Arifin, 2018). It has been done until now the presidential candidates and vice president campaigned to compete in a healthy manner not to bring down other parties and not harm any party and with this campaign period it is very beneficial for the people of Indonesia. Moreover they compete to carry out their work program for Indonesia. In realizing of political system, general election between the legislative election and the election president, there are some things that become opportunities and challenges in perspective politics, both for political parties, government, voters, and election organizers. Therefore, efforts are needed regarding how to design simultaneous inward elections political perspective, namely by reforming the representative system, the electoral system, the system party parties, and in carrying out simultaneous general elections in 2019 had a goal creating effective governance (Solihah, 2019).

KPK Chairman Agus Rahardjo proposed that political parties get financed by the government. It is expected that with funding from the state, democracy will be cleaner from corruption. There are political parties that agree, some do not agree. This news was announced on December 4, 2018 on a private television program. When political parties divert funds from the government, sanctions need to be implemented. It is shown by the disqualification from participation in elections (Romadhan; Khanifah; Sihidi; \& Kamil., 2019).

There are some political parties that agree and disagree with the idea put forward by the KPK. In one side, it is a very good idea to eliminate corruption when the campaign takes place and it does not harm other people or parties. Secondly, political parties are not difficult to find funds for their campaign. In other side, the money used for the political party's campaign comes from the state budget and it is better when the state budget could be concerned to community's development and its economy.

The money used for political parties in the campaign period are, (a) Legal entity status in accordance with the Law on political parties. Which means that each person who entered into a cooperation agreement on the basis of realizing unity and unity which has been determined by law, (b) Has management in all provinces, which means that the person is acting in state institutions that have been determined according to the person and carry out their obligations and responsibility, (c) Has management in $75 \%$ of the number of districts/cities in the province concerned, (d) Having management in 50\% of the number of sub-districts in the district/city concerned (e) Include at least 30\% of women's representation in the management of central political parties, (f) Has a membership of at least 1,000 people or 1/1,000 of the total population in the management of political parties as referred to in number three which is proven by ownership of a member card, (g) Having a permanent office for management at the central, provincial and district/city levels until the last stage of the election, (h) Submitting the name, symbol and image of the political party to the KPU, (i) and include the election campaign fund account number on behalf of the political party to the KPU. That is the condition when political parties want to nominate themselves as presidential, presidential, or legislative elections. Indonesia is not only a country that has Pancasila democracy but is also referred to as a legal state, because there is a clear correlation between the rule of law, which relies 
on the constitution, with people's sovereignty, which is carried out through this democratic system (Mulyadi, 2018).

Based on the various problems above, an important role is the emergence of leaders with election integrity in Indonesia certainly becomes a challenge and opportunities for all elements of the nation within improvement of the political and democratic system in Indonesia. The elections in Indonesia can be carried out well needed sincerity from the government and members of parliament not to caught up in an opportunist political game and pragmatically, implementation in Indonesia must be a democratic meaningful to the new electoral system in Indonesia. This paper was made as an effort see what aspects need to be done in the succession of the elections in Indonesia within a framework of good justice and democracy.

\section{Literature Review}

The idea of simultaneous general elections in 2019 brought political consequences nationally and area. Decision of the Constitutional Court Number 14 / PUU-XI / 2013 case of testing Law Number 42 of 2008 Regarding the General Election of the President and Vice President is a final decision (Triono, 2019). Implementation of the Constitutional Court's decision this certainly has implications and great challenges for the Indonesian people in improving the political system and more mature democracy. The effectiveness of simultaneous elections in 2019 is still a public debate, 'Law The New Election' which was ratified as a legal umbrella for the 2019 elections is still in the process of judicial review at the Constitutional Court. Theoretically the 2019 simultaneous elections are possible to be carried out by considering Indonesian political dynamics have improved since the reform era. The main thing that must be an agreement together is that the electoral system is only an instrument in a democratic system, this instrument certainly can adjust and change depend on the state conditions and goals. The 2019 election will be an indicator in a direct democratic system where people can participate in politics.

Presidential elections in 2019 struggle to diminish the hatred, hoaxes, black campaign, and various things that can provoke divisions among communities. It is hoped that each people who has different opinions about political candidates not to be fragmanted and influence the harmony of Indonesia. It is acknowledged that Indonesia has multicultural background of society as well as the diversity of religion practices (Huda \& Fadhlika, 2019). The political interests are above the interests of the people. For the nation's leaders and prospective partners who will compete in 2019 elections, are expected to promote dialogue for the progress of the nation and constructive solutions. Compared to looking for lacking from the opposing camp, the good idea is to give a solution for a more advanced Indonesia.

The formation of identification through the socialization of values and norms which develops in one group of people functions as a filter against other norms that are considered different or contradictory. In this case group Nahdilyin who have different norms will reject the influence that comes from the Muhammadiyah community group (Nurjaman, 2017). The dynamics of factionalism in internal parties in post New Order era increasingly high tensity due to competition among cadres to fight for power in the regions as a form of autonomy. Political pragmatism that bursts added behaviour nepotism in the election competition has pushed into competition new internal form of group clique which pivots on 
personal. With thus, in internal party factionalism is based on functionalist groups have shifted to nepotically based groups that have emerged from closeness during leadership (Nurjaman, 2018).

In the other case about dynamic of elections governance, registration implementation and the factual verification process in the Padang City KPU is in accordance with what is has been ordered by law, and from 16 political parties that are followed the factual verification process as a participant in the 2019 election had passed and qualify to be a participant in the 2019 election, and the implementation of factual verification in the city of Padang does not have significant problems, despite the changes that are occurred after the Constitutional Court's decision. But even so KPU has been running his duties well in accordance with the rules and laws (Putra; Ariany; \& Syahrizal., 2019). Based on Syiyasah Syar'iyah's perspective, the decision of the Constitutional Court is fair for political parties participating in elections for people who are willing to become candidate/ vice president, and for people who want to test their election. This decision also aims to reduce the number of non-voter groups. The Constitutional Court's decision also contains the principle of unity and alliance, because it aims to stop the practical political interests that lead to the collapse of unity (Prasetyoningsi, N;Wijayanti,; Syaroni, 2019).

Figure 1: Relationship between popular sovereignty, elections and democracy

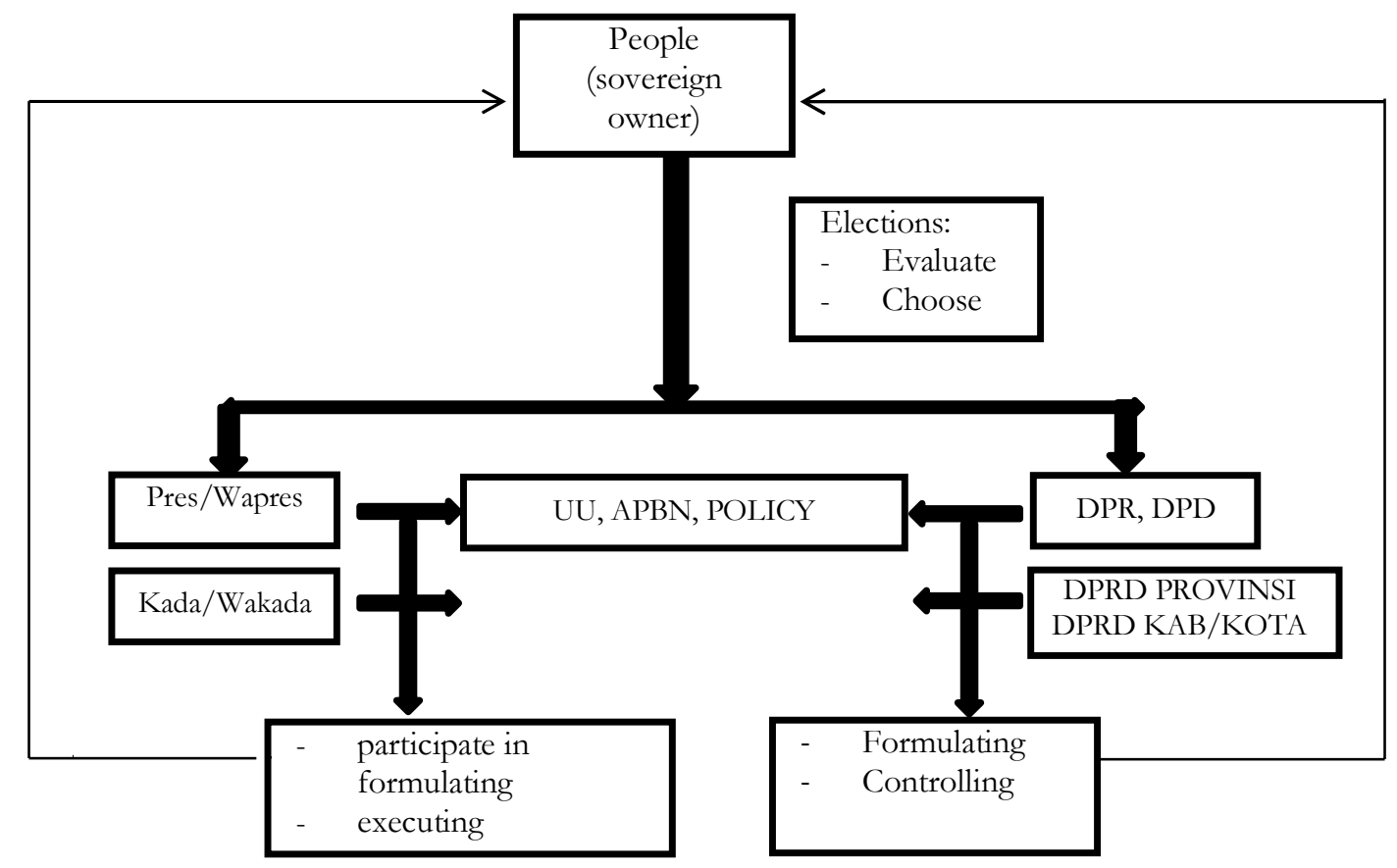

Source: (Arrsa, 2014).

Based on the development of practice of democracy in the modern era, it is no longer possible to be carried out directly, in the sense that all people gather to make decisions and all people jointly run the government. Therefore representative democracy emerges, in which the people elect their representatives to make state decisions and elect officials who will carry out these decisions both at the central and 
regional levels. The decisions taken and their implementation must be in accordance with the aspirations and interests of the people. The people as owners of sovereignty do not lose their sovereignty, even though they have chosen their representatives (Arrsa, 2014). The people evaluate the performance of their representatives, and if they are seen as failing or inappropriate, the representative will not be elected again. In the following constitutional construction the author describes the relationship between popular sovereignty, democracy and elections in an order as in figure 1.

Based on the figure 1, the election is part of an effort to translate democratic practices and people's sovereignty so that the government formed represents the common will of all national elements to form and continue the concept of the state. In this context, of course, the organization of the State is present and needed by the citizens of the political community so that their shared interests can be protected or promoted through the establishment and use of a mechanism called the State. If a nation-state is established based on the principle of popular sovereignty and is aimed at all nations consisting of diverse ethnic cultures, and religions. Then the mechanism of democracy is the only choice in the process of forming a collective agreement (Lestari, Asikin, \& Risnain, 2019).

\section{Method}

This writing is normative article where the data presented are qualitative. This writing only examines cases and facts obtained through various print and online media relating to the holding of elections in Indonesia. Its also the collected data on General Election in Indonesia due to mining activities various place and therefore to analyse the potential democracy. These secondary data were getting from journal, research, books and news paper. In addition, quantitative data were support from narrative in order to provide more Comprehensive analysing (Creswell, 2009).

These secondary data was from primary observation in Indonesia, during the observation activity of general election for this research. Democracy phenomenon aim to representative democratic practices and people's sovereignty so that the government formed represents the common will of all national elements to form and continue the concept of the state.

\section{Result and Discussion}

\section{Democracy and General Elections in Indonesia}

The term democracy comes from Greek, namely "demos" which means people and "kratos" means government. so democracy is a people's government or a government where the people hold the highest sovereignty or the people are included in the government of the country (Pasaribu, Sumadinata, \& Muradi, 2018). In addition to the democracy, many systems have been implemented. democracy can also be called as a forum for the government to display its desire to regulate or control the people. Democracy has been interpreted as a political system that seeks form in the movement of society through the concept of civilization. Can do something in the name and authority of government responsibility.

In the political science literature there are principles of political system pillars that are democratic (Solihah, 2019), namely (1) guaranteed rights and freedoms of citizens; (2) participatory democracy; (3) system selecting and replacing State administrators; (4) rule of law; (5) check and balance separation of power; (6) 
effective government and opposition; (7) regional government based systems decentralization; (8) Correlation of Simultaneous Elections with Simple Multi Parties as Strengthening Presidential system understands constitutionalism; (9) government by the majority party; (10); democratic culture or civic culture as the attitudes and behaviour of citizens .

Indonesia is one country that applies a democratic political system. Democracy applied in Indonesia has a slogan that is from the people, by the people, and for the people. One of the means of the democratic political system in Indonesia is General Election. General elections are a manifestation of freedom of opinion and freedom of association. General elections in Indonesia adhere to the principle of "Luber" which stands for "Direct, General, Free and Secret". The origin of Luber has been around since the New Order era. Then in the reform era there was also the principle of "Jurdil" which stands for "Honest and Fair (Fitriana, 2015). And people used to say it with LuberJurdil. This Jurdil illustrates the future so that the development of society in Indonesia can be honest and fair in choosing a leader that we will carry out in the future.

A democratic political system would not work without a system party. But the party system alone is not enough to produce democracy (Putra; Ariany; \& Syahrizal., 2019). A strong democratic political system requires political parties functional and democratic. In addition, political parties must also well institutionalized and competitive. Political parties don't just become channel of citizen political participation. They also play a role integrating individuals and groups in society into political system

In terms of its functional, democracy can be divided into two categories, namely direct democracy and representative democracy (indirect). In direct democracy all citizens directly participate in the withdrawal and termination of every regulation that will be enforced in the community. In the era of Ancient Greece, Athens where democracy was applied for the first time in the world was able to carry out direct democracy because an assembly was able to accommodate citizens who still consisted in a limited or small amount. Now in the modern era where the area and the number of citizens are already so large with the problems faced increasingly complex, then it is no longer possible for democracy to be directly implemented.

Democracy that is commonly implemented is representative democracy (indirect) with various variations. Direct democracy is held only in the election of the executive body, while for the legislative function as an institution overseeing the course of government, the people directly control it. But because of the daily activities of the people in fulfilling their needs, a special institution is needed to oversee the administration of the government such as parliament (senate). In direct democracy, between those who elect and be elected are directly related. For example, prospective executive members and their families directly face their admirers, comment on their work plan and voters (people) directly assess the person (person or individual). This direct democracy can use another system that is proportional, but of course it is discordant because it uses various symbols, although voters want to deal directly with the person to be elected and will represent them in parliament later.

In indirect democracy, general elections are usually held to elect leaders. The general election is a district system or proportional system. In general elections the people do not directly elect their candidate leaders but through representatives in 
the legislature first. For example indirect democracy: To elect the Indonesian president, the people did not directly vote but passed representatives, namely the people first elected their representatives in the DPR, which after the DPR was added with regional envoys to become MPRs, then the MPR chose the president (Pasaribu et al., 2018). The Indonesian state chose a presidential system of government which actually has advantages and disadvantages compared to the system parliamentary government. For president, we certainly know if a sense of dissatisfaction among the people, the people of Indonesia have to wait the next five years to choose a leader who will replace the elected leader. However, there are also benefits if we use a presidential system, where the political conditions are in governance is stable.

For that reason, community, stakeholders, party cadres and all layers the people in Indonesia are expected not to be fanatic about faction that can be one way to maintain unity. At the Presidential Election, many parties wanted to interfere in the party this democracy. Upholding values that are based on interest, for the Indonesian people, multiculturalism is a thing inevitability and necessity. Racial, ethnic, linguistic, and cultural diversity religion is a characteristic and strength of the Indonesian nation distinguish it from other nations. However, lately there is the tendency of some citizens of the nation and community groups to denying the multicultural nature inherent in the Indonesian people since hundreds of years ago. That caused the Indonesian people to return confronted with a troubling situation, namely the threat of disintegration nation. a feeling that ties the cohesiveness of the unity of the island community is a sense of the same fate as a nation.

\section{The Challenges of Law Enforcement and State Stability on General Elections in Indonesia}

In Indonesia, elections (elections) are the process of selecting people to fill certain political positions. These positions are diverse, ranging from the president, people's representatives at various levels of government, to the village head. In the broader context, elections can also mean the process of filling in positions such as the student council president or class leader, although for this' election 'is used more often. Democratic election and presidential election party illustrates that sovereignty in the hands of the people, where the government comes from the people, by the people, and for the people. In elections there is political contestation encourage potential leaders to make efforts to win the general election. This is what cause different reactions among people about their views on the efforts made by the contestants

Basically, political parties are born to facilitate parties people for their right to be able to do politics in choosing and promoting country on the mandate. A political party cannot have only one party, it cannot be said to be democratic. Then with there is a diversity of arguments to advance the country. Political parties this can be used as a positive thing to work on things government and state. Political parties exist for the benefit of the state and the people. However, political parties are often used as weapons themselves to make use of power of its own caretaker. Like in Indonesia, the management / leader gives promises and mandates if he is elected in a political party.

To overcome the various potential democracy, the party politics as stated above requires various mechanisms supporting, First, an internal mechanism that 
guarantees democratization through the participation of members of political parties in decision making. Arrangements regarding this matter need to be formulated in writing. In The budget also needs to be embedded in code of ethics, code of laws, code of conduct.

According to Ali Moertopo, the definition of Election is as follows: "In essence, elections are a means available to the people to carry out their sovereignty in accordance with the principles that are governed by the Preamble of the 1945 Constitution. Election itself is basically a Democratic Institution that elects representatives of the people in the MPR, DPR, DPRD, which in turn are tasked to jointly with the government, determine the politics and running of the State government".

Elections which are the process of changing power must be directed to be able to elect people's representatives who have integrity and competence in their respective fields and have many experiences that have been felt in their lives so when they will choose leaders for the State, look at him first how to interact with the community, prosper society, so that people are not deceived by what they are talking about in public when delivering their vision and mission in campaigning (Huda \& Fadhlika, 2019). The people's representatives and their political parties are those who have a vision of governance reform, where the vision is reflected in their attitudes and behaviour, and are clearly translated into the platform of their party programs. We can see the attitudes and behaviour of candidates and their political parties whether they are good and the farthest from members of corruption, then able to overcome the problems of the community that are declining in social and economic conditions. Anti-corruption is the main factor in candidates because usually the authorities will be tempted by negative things like this corruption.

There are some that must be observed in democratic elections, namely: (1) In this process must be carefully and carefully seen in the election, whether the party has a clear mechanism regarding the party's financial system and campaign funds and does not get money from parties that have the potential to affect their independence and integrity; whether candidates and parties are able to control themselves not to use money politics in the determination of candidate lists and campaigns. In short, candidates and parties are able to release themselves from the issue of money politics in each stage of the election. So that leadership is not easily deceived by anyone who wants to destroy himself and his country. (2) Candidates and parties must be able to show that they have a clear vision, commitment, program and platform in eradicating corruption. They are also willing to sign the fact of integrity not to commit acts of corruption in their capacity as legislators or public officials. So that candidates are trusted with the community and are believed that the candidate deserves to lead a country that will be led and change their country better. (3) Candidates have been proven to have committed acts of KKN when carrying out their mandate as members of parliament or other public officials and the party has no clear stance and program to eradicate corruption in the previous government and follow up on appropriate penalties for corruption in the Indonesian State not given the opportunity to re-nominate political parties or serve as board members in any institution (Arrsa, 2014).

The implementation of democratic elections does not automatically guarantee the granting of voting rights from each voter to be carried out in an 
aspirational manner or in accordance with the wishes or autonomous will of each voter. In many ways, the aspirations of voters are no longer autonomous or sterile from various influences, both political, economic, ideological, kinship and religiosity. Political influence occurs through the obedience of voters to political parties, while economic influences appear through money politics (vote buying) (Octarina \& Djanggih, 2019). The influence of ideology and religiosity is seen through the role of developing religious or ideological figures, while the influence of kinship is seen through the influence of traditional leaders or family figures in an environment.

Democratic elections should be carried out in accordance with the principles of elections adopted by Indonesia, namely LUBER JURDIL. In the LUBER and JURDIL election principles, supervision can be carried out. The supervision is not only carried out by Panwaslu, we also have to play a role in the supervision. The community can monitor both directly and indirectly in the process of running democracy/elections. Direct monitoring can be carried out during the democratic process. not only the Election Supervisory Committee and we play a role, but the Election Supervisory Committee will also continue to carry out its duties in this election, whether the presidential election, legislative members or others. Each person must carry out their duties responsibly.

There are weaknesses of democratic elections held every 5 years, as followed: 1) Wasteful multiparty system: It is clear that a very large party system wastes a lot of budget. Of course this situation arises because more and more people are interested in becoming politicians. Isn't the job of sitting, rocking feet, cheap enough and looking for sensation in the media but the income (salary) and facilities obtained are very high beyond all those who work around the workplace. So, people who like assets and positions have capital just a little directly for a new party. Various new names also appear to be chosen in the periodic community party event. 2) Personal expense campaign: capital in the hands is willing to be sacrificed to pay dowry to be presented by the political party's red carpet. The person even borrowed here and there to be able to acquire huge campaign costs to win him. Then the huge sacrifice was relinquished because knowing exactly when he was in office / lead there would be a lot of funds to be asked for money by force at will without anyone knowing. 3) Private cost campaign: Of all the shortcomings of democracy, this is the most destructive and strange weakness. The only thing that arises is because the "cake shop is looking for new employees but an electronics store that finances the process." This is clearly a political culture that has existed since the reformation. This kind of democratic practice is clearly the root of corporate corruption in private versus government. 4) Waste of campaign material: These various forms of waste are carried out because the interest to win is very high. The funds disbursed by the private sector and private bags are hot money so that their use seems rushed and careless. Providing brochures, clothes, hats, envelopes and various other accessories to bribe the wider community who are not members of the party and after this waste is an oversight of democracy that we should turn back to the right function. 5) Politicians double job: Pay attention to their work, not only to defend the interests of the people but a lot of other activities that are more important. Maybe there are also those who work as entrepreneurs as well as regents/mayors/governors/presidents. Maybe there are also those who work as artists and members of the board and there are many other forms of double jobs which show that these people are very thirsty 
with money and power, 6) Injustice of the government dividing resources: The enormous power struggle made officials also give up many valuable things in order to become winners. all of this is due to struggle. The interest of politicians in fighting for victory is very high because the prizes offered are also very high. If only, the government controls all the resources that exist in its territory (nationalization of private companies), and surely this can be shared fairly and equitably with the entire community.

\section{Conclusion}

Indonesia is the state of law that embraces the democratic system. one of its embodiments is the general election because its sovereignty is in the hands of the people, although almost all the nations embrace the fundamental sovereignty of the State which means sovereignty/decision is in the hands of the people and power derived from the will of the people. Democracy includes the theory of people's sovereignty which means the teaching that determines that the highest source of power or leniency in a State is in the hands of the people. As such, the rule and power that the State is doing can not contradict the will of the people. This theory has the purpose of a prosperous country and achieves its ideals. Democracy calls for a separate term that is explained in the principle of sovereignty of the people, namely constitutional democracy, democracy of the people, and democracy Pancasila.

\section{References}

Arrsa, R. (2014). Pemilu Serentak Dan Masa Depan Konsolidasi Demokrasi. Jurnal Konstitusi, 11(3), 515-537.

Creswell, J. W. (2009). Research Design : Qualitative, Quantitative, and Mixed Methods Approaches. 35(2), 2-4.

Fitriana, M. K. (2015). Peranan Politik Hukum Dalam Pembentukan Peraturan Perundang- Undangan Di Indonesia Sebagai Sarana Mewujudkan Tujuan Negara. 1-27.

Huda, K., \& Fadhlika, Z. A. (2019). Pemilu Presiden 2019 : Antara Kontestasi Politik dan Persaingan Pemicu Perpecahan Bangsa. 547-562.

Lestari, M., Asikin, Z., \& Risnain, M. (2019). Presidential Threshold Concept in the Democratic Perspective in Indonesia. International Journal of Scientific Research and Management, 7(06), 149-150. https://doi.org/10.18535/ijsrm/v7i6.sh01

Mulyadi, D. (2018). Concurrent Regional Elections Phenomenon As a Political Recruitment in Indonesia. Jurnal Dinamika Hukum, 18(1), 87. https://doi.org/10.20884/1.jdh.2018.18.1.843

Mulyadi, D., \& Utami, T. K. (2017). The Dispute Settlement Model of Regional Head Election Perspective Theory of Legal System in Indonesia. International Journal of Nusantara Islam, 5(1), 97-106. https://doi.org/10.15575/ijni.v5i1.1054

Nurjaman, A. (2017). Cleavage Agama Di Tingkat Lokal, Indonesia : Identifikasi Partai Tanpa Komitmen Electoral. 3(2), 43-66.

Nurjaman, A. (2018). Masa Depan Faksionalisme Politik Golkar Pasca Orde Baru. $4(2), 34-48$. 
Octarina, N. F., \& Djanggih, H. (2019). Legal Implication of Black Campaigns on The Social Media in The General Election Process. Jurnal Dinamika Hukum, 19(1), 271-282. https://doi.org/10.20884/1.jdh.2019.19.1.2115

Pasaribu, T., Sumadinata, R. W. S., \& Muradi, M. (2018). Pemilu Berintegritas (Studi Pendaftaran Pemilih Terhadap Pengguna Surat Keterangan Domisili Dalam Pilkada Samosir Tahun 2015). Journal of Governance, 3(2). https://doi.org/10.31506/jog.v3i2.4427

Prasetyoningsi, N;Wijayanti,; Syaroni, A. \& L. (2019). The Implementation of Siyasah Syar' iyah Principles in The Constitutional Court Decision Regarding to The Simultaneous Election 2019. 7(2), 108-128.

Putra; Ariany; \& Syahrizal. (2019). Tata Kelola Verifikasi Partai Politik Peserta Pemilihan Umum Tahun 2019. 9(1), 107-123.

Romadhan; Khanifah; Sihidi; \& Kamil. (2019). The Role Of Bossism In Practice Of Gambling Election Of Village Head In Batu City. Web Jurnal Online: Jurnal.Unmuhjember.Ac.Id, 53(9), 1689-1699. https://doi.org/10.1017/CBO9781107415324.004

Solihah, R. (2019). Peluang dan tantangan pemilu serentak 2019 dalam perspektif politik. 3(1), 73-88. https://doi.org/10.14710/jiip.v3i1.3234

Triono. (2019). Menakar Efektivitas Pemilu Serentak 2019. 2(2), 156-164.

Yustikarini, D., Alika, H., \& Arifin, R. (2018). Membaca Dinamika Demokrasi dalam Penyelenggaraan Pemilihan Umum di Indonesia. 467-468. 